\title{
ANALISIS KELAS KESESUAIAN LAHAN UNTUK TANAMAN \\ BAWANG MERAH DI DESA PASARAN PARSAORAN KECAMATAN NAINGGOLAN KABUPATEN SAMOSIR
}

\author{
Desmi Sianturi 1, Nahor M. Simanungkalit 1 \\ ${ }^{1}$ Jurusan Pendidikan Geografi Fakultas Ilmu Sosial Universitas Negeri Medan \\ Jln. Willem Iskandar Psr V Medan Estate Medan 20211 \\ Email: nahor.simanungkalit@yahoo.com
}

\begin{abstract}
ABSTRAK
Penelitian ini bertujuan untuk mengetahui : 1) Karakteristik kualitas lahan (temperatur, curah hujan rata-rata, drainase, tekstur, kedalaman perakaran, KTK, pH, N-total, K2), $\mathrm{P}_{2} \mathrm{O}_{5}$, kemiringan lereng, batuan di permukaan dan singkapan batuan), 2) Kelas kesesuaian lahan untuk tanaman bawang merah di Desa Pasaman Parsaoran Kecamatan Nainggolan Kabupaten Samosir. Populasi dalam penelitian ini adalah seluruh lahan kering di Desa Pasaman parsaoran seluas $1055 \mathrm{Ha}$. Sampel ditentukan secara Purposive Sampling, dipilih berdasar 2 (dua) ketentuan tertentu : 1) ketinggian tempat yang berdampak pada suhu mikro, dan 2) bentuk relief daerah penelitian yang memiliki topografi bergelombang dengan menggunakan kontur interval 10 meter, sehingga diperoleh sampel sebanyak 4 titik. Teknik pengumpulan data yang dilakukan ialah Observasi, teknik pengukuran dan studi dokumenter. Data dianalisis secara deskriftif kualitatif. Hasil penelitian menunjukkan bahwa 1) Kualitas lahan di Desa Pasaman Parsaoran tidak baik untuk tanaman bawang merah akibat ketersediaan air (w) yang berlebih. 2) Kelas kesesuaian lahan untuk tanaman bawang merah berada pada kelas Nw karena kondisi curah hujan yang tinggi. Lahan yang memiliki pembatas paling banyak berada pada wilayah dusun III dengan faktor pembatasnya curah hujan (w) pada kelas $\mathrm{N}, \mathrm{pH}$ dan lereng pada kelas S3 (sesuai marginal), suhu, drainase padakelas S2. Lahan yang memiliki penghambat paling sedikit berada pada dusun II dengan faktor pembatas ketersediaan air (w) berada pada kelas $N$. Nilai Ph, suhu, KTK, pada kelas S2 dan faktor pendukungnya ialah tekstur, kedalaman efektif tanah, $\mathrm{N}$-total, $\mathrm{P}_{2} \mathrm{O}_{5}$, batuan di permukaan, dan singkapan batuan pada kelas S1.
\end{abstract}

Kata kunci: Kelas kesesuaian lahan, Bawang merah

\section{PENDAHULUAN}

Tutupan lahan (land cover) merupakan perwujudan fisik obyekobyek yang menutupi lahan tanpa mempersoalkan kegiatan manusia terhadap obyek-obyek tersebut (Delita, 2016). Kondisi penutupan lahan identik dengan keadaan vegetasi yang terdapat pada suatu areal. Keadaaan tajuk tanaman baik horizontal maupun vertikal merupakan faktor yang sangat menentukan untuk mengurangi energi aliran, meningkatkan kekasaran, mengurangi kecepatan aliran permukaan dan selanjutnya akan mengurangi kemampuan aliran untuk mengikis tanah dan mengangkut sedimen.

Efektifitas tanaman sebagai media penutup lahan dalam mencegah erosi tergantung pada tinggi dan kontinuitas kanopi, kerapatan penutup lahan dan kerapatan perakaran. Seperti yang diketahui bahwa makin tinggi tempat jatuh butiran hujan makin tinggi kecepatannya pada saat mencapai permukaan tanah. Oleh karenannya ketinggian tanaman berperan sangat penting, semakin tinggi tanaman akan semakin besar energi kinetik butiran air 
hujan yang jatuh dari tanaman itu (Rahmad, 2013).

Bawang merah merupakan tanaman holtikultura yang tersebar di beberapa daerah di Indonesia yang digunakan sebagai bumbu masakan dan memiliki kandungan zat yang bermanfaat bagi kesehatan. Pada tahun 2009 terdapat 9 provinsi sentra produksi bawang merah yang mendominasi produksi bawang merah nasional yaitu mencapai 96\%, daerah tersebut ialah Sumatera Utara, Sumatera Barat, Jawa barat, Jawa Tengah, Daerah Istimewa Yokyakarta, Jawa Timur, Bali, Nusa Tenggara Barat dan Sulawesi (Wibowo, 2009).

Seiring dengan persebaran tumbuhnya tanaman bawang merah, beberapa daerah di Indonesia telah mengalami penurunan produksi bawang merah. Menurunnya produksi ini disebabkan oleh serangan hama-penyakit, keadaan cuaca ekstrim serta kualitas lahan yang menurun. Kualitas lahan merupakan parameter yang digunakan untuk mengetahui kesesuaian lahan. Berhasil atau tidaknya pertanian dapat dipengaruhi oleh kesesuaian lahan. Kesesuaian lahan ialah tingkat kecocokan tanaman pada suatu lahan berdasarkan ada atau tidaknya faktor penghambat yang dihasilkan dalam bentuk kelas-kelas. Meningkatnya suatu penghambat dapat diakibatkan oleh eksploitasi berlebihan yang merupakan bentuk nyata pemanfaatan yang melebihi daya dukung tanah.

Kabupaten Samosir merupakan salah satu penyumbang bawang merah yang cukup besar di Sumatera Utara. Kabupaten ini berada di wilayah Pegunungan Tengah Sumatera Utara dengan ketinggian 700 - $1.700 \mathrm{~m}$ dpl. Daerah ini termasuk wilayah pertanian yang sangat mengandalkan curah hujan untuk keberhasilan pertaniannya. Bawang merah merupakan salah satu komoditi andalan Samosir dengan nama varietas lokal Samosir yang memiliki ciri khas yaitu warna lebih cerah, kadar air lebih rendah, dan memiliki rasa lebih pedas dengan harga jual yang tinggi dipasaran (Sianipar, 2015).

Rentang tahun 2000 - 2005, terjadi gagal panen yang mengakibatkan produksi bawang merah menurun. Pada tahun 2006 penanaman kembali dilakukan, namun masih dalam luasan kecil sehingga belum terdapat data luasan lahan serta jumlah produksi bawang merah di tingkat kabupaten hingga tahun 2010. Tahun 2011-2013 diperoleh data dari Dirjen Holtikultura (2016) dengan jumlah produksi bawang merah yaitu 1,679 ton; 1,504 ton dan 1,114 ton dan terlihat masih terjadi penurunan produksi yaitu 0,175 ton dan 0,390 ton.

Nainggolan merupakan salah satu kecamatan yang berada di Kabupaten Samosir yang memiliki 13 desa dan dua kelurahan, daerah ini turut mengalami penurunan produksi bawang merah yang mengakibatkan petani merasa jera untuk mengusahakannya kembali. Berdasarkan survey awal, penyebab kegagalan panen yang terjadi akibat serangan Lalat Liriomyza dan menurunnya kualitas lahan akibat penggunaan lahan yang intensif selama beberapa tahun sebelumnya. Pada tahun 2008 pemerintah kabupaten membentuk BPK (Badan Penyuluhan Kecamatan) yang membidangi penyuluhan tentang pertanian di Kecamatan Nainggolan dan pada tahun itu pula penyuluhan tentang penanaman bawang merah mulai dilakukan.

$$
\text { Data BPK Nainggolan }
$$

menunjukkan bahwa Desa Pasaran Parsaoran kembali melakukan penanaman bawang merah yaitu tahun 2009 memiliki luas tanam 2,5 ha, namun terjadi penurunan penanaman pada tahun 2010 seluas 1,3 ha. Penanaman bawang merah terus berlanjut hingga 2015 luas tanam bawang merah 1,7 ha, dan terjadi peningkatan pada tahun 2016 seluas 0,3 ha. Hal ini menunjukkan bahwa bawang merah kembali diusahakan setelah beberapa selang waktu terhenti. Namun 
gé grafi

petani belum mengetahui kondisi lahan saat ini.

\section{METODE PENELITIAN}

Penelitian ini berlokasi di Desa Pasaran Parsaoran Kecamatan Nainggolan Kabupaten Samosir dengan populasi seluruh lahan kering seluas 414,5 Ha. Sampel diambil secara Purposive Sampling yaitu dengan memperhatikan bentuk relief daerah penelitian menggunakan peta kontur berinterval $10 \mathrm{~m}$ yang mempertimbangkan kondisi lahan lereng, lahan landai, lahan punggung dan lahan lembah sehingga diperoleh sampel sebanyak 4 titik yang ditampilkan pada gambar 1.

Variabel dalam penelitian ini adalah karakteristik lahan yaitu: temperatur rata-rata, Curah hujan ratarata tahunan, kelas drainase tanah, tekstur tanah, kedalaman efektif tanah, KTK, $\mathrm{pH}$ tahah, N-Total, P2O5, Tersedia, lereng, batuan dipermukaan dan singkapan batuan.

Data dikumpulkan dengan menggunakan teknik observasi, teknik pengukuran dan study dokumenter. Alat yang digunakan ialah kamera digital, alat tulis, bor tanah, GPS, plastik sampel, meteran dan abney level meter dan bahan yang digunakan ialah sampel tanah, peta administrasi, peta kontur dan peta tutupan lahan Desa Pasaran Parsaoran. Data yang telah diperoleh dari hasil penelitian kemudian dicocokkan atau di matching dengan teori Litbang Pertanian dan hasil modifikasi Siswanti (2006) dan kemudian dianalisis menggunakan teknik analisis deskriptif kualitatif.

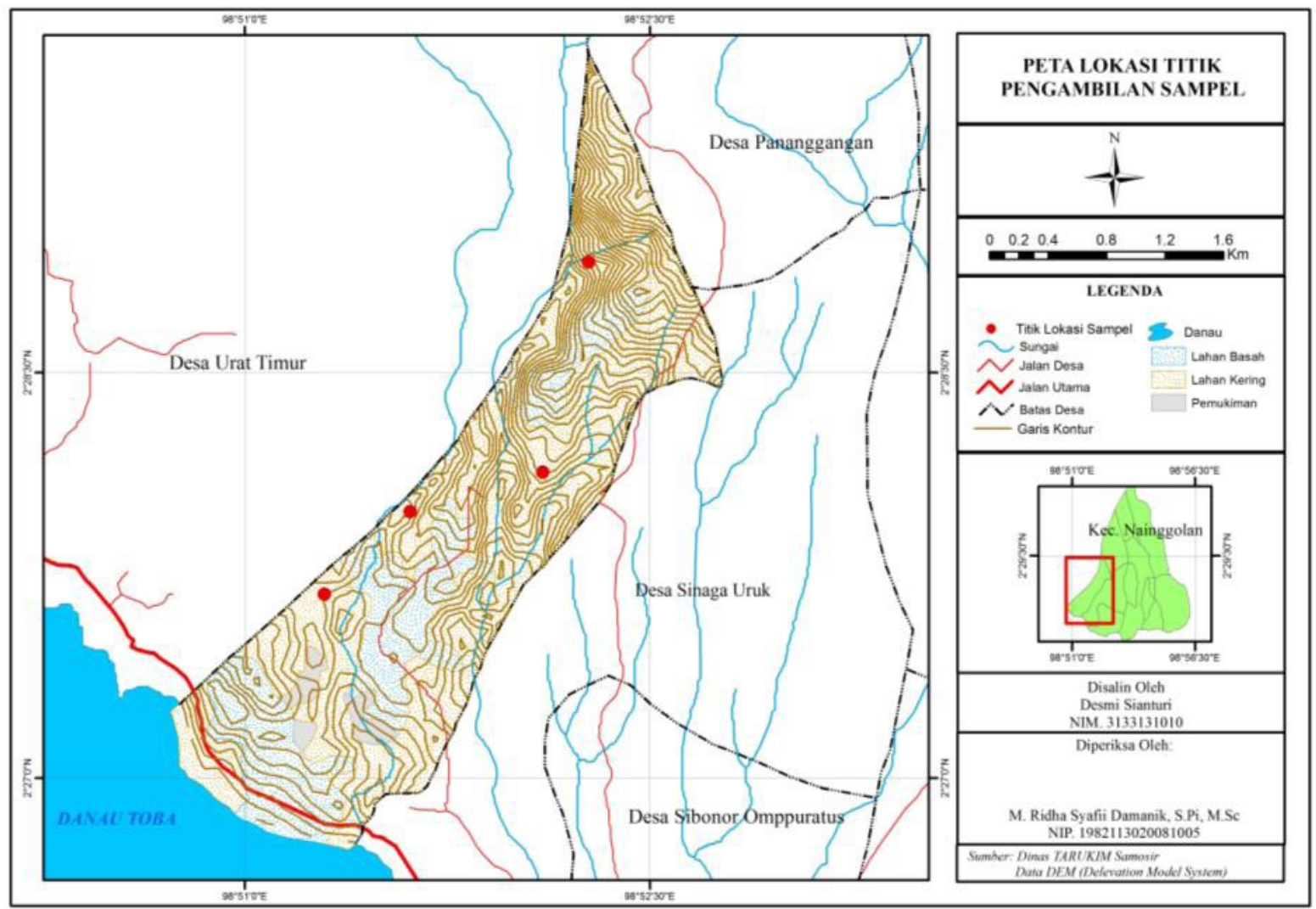

Gambar. 1 Titik Lokasi Pengambilan Sampel

\section{HASIL DAN PEMBAHASAN}

Berikut data karakteristik lahan serta kelas kesesuaian lahan setelah dilakukan pencocokan dengan syarat tumbuh tanaman bawang merah berdasarkan Litbang Pertanian. 


\section{Lahan Lereng}

Pada lahan lereng, memiliki pembatas yang cukup besar, ketersediaan air dan lereng merupakan pembatas utama. Lahan lereng memiliki kelas kesesuaan yang cukup beragam. Faktor Pembatas pada lahan ini ialah Regim temperatur (c) yaitu suhu desa yang berada pada kelas S2, Ketersediaan air (w) berada pada kelas N. Faktor suhu (c) dan ketersediaan air $(\mathrm{w})$ merupakan pembatas yang sama pada setiap lahan karena suhu (c) dan ketersediaan air (w) merupakan kualitas lahan yang permanen yang dapat mewakili keseluruhan Desa Pasaran Parsaoran. Pembatas berikutnya ialah kondisi perakaran (f) yaitu drainase tanah berada pada kelas S2, retensi hara(n) yaitu KTK dan pH tanah pada kelas S2 dan S3, ketersediaan unsur hara (r) dengan karakteristik lahannya $\mathrm{K} 2 \mathrm{O}$ yang rendah dan kondisi lereng berada pada kelas S3. Sedangkan tekstur, kedalaman tanah, N Total, P2O5, batuan permukaan dan singkapan batuan menjadi faktor pendukung yang berada pada kelas S1.

Tabel I. Karakteristik Lahan Pada Lahan Lereng

\begin{tabular}{|c|c|c|c|c|c|}
\hline \multirow[t]{2}{*}{ No. } & \multicolumn{5}{|c|}{ Lahan Lereng } \\
\hline & Kualitas lahan & $\begin{array}{c}\text { Karakteristik } \\
\text { Lahan }\end{array}$ & $\begin{array}{c}\text { Hasil } \\
\text { Pengukuran/ } \\
\text { Pengamatan }\end{array}$ & Kriteria & $\begin{array}{c}\text { Kelas } \\
\text { Kesesuaian } \\
\text { Lahan }\end{array}$ \\
\hline 1 & $\begin{array}{l}\text { Regim temperatur } \\
\text { (c) }\end{array}$ & $\begin{array}{l}\text { - Temperatur rata- } \\
\text { rata }\end{array}$ & $19,6^{\circ} \mathrm{C}$ & - & S2 \\
\hline 2 & $\begin{array}{l}\text { Ketersediaan air } \\
(\mathrm{w})\end{array}$ & - Curah hujan & $1835 \mathrm{~mm}$ & - & $\mathrm{N}$ \\
\hline 3 & $\begin{array}{l}\text { Kondisi perakaran } \\
\text { (f) }\end{array}$ & $\begin{array}{l}\text { - Drainase } \\
\text { - Tekstur } \\
\text { - Kedalaman tanah }\end{array}$ & $\begin{array}{l}\text { Agak buruk } \\
\text { Pasir }(49 \%) \\
\text { Debu }(22 \%) \\
\text { Liat }(29 \%) \\
>60 \mathrm{~cm}\end{array}$ & $\begin{array}{l}\text { Agak } \\
\text { buruk } \\
\text { Lempung } \\
\text { liat } \\
\text { berpasir } \\
\text { - Dalam } \\
\end{array}$ & $\begin{array}{l}\text { S2 } \\
\text { S1 }\end{array}$ \\
\hline 4 & Potensi hara (n) & $\begin{array}{l}\text { - KTK liat } \\
\text { - } \mathrm{pH} \mathrm{H}_{2} \mathrm{O}\end{array}$ & $\begin{array}{l}9,42 \% \\
5,71 \%\end{array}$ & \begin{tabular}{|ll} 
- & Rendah \\
- & Sangat \\
& masam \\
\end{tabular} & $\begin{array}{l}\text { S2 } \\
\text { S3 }\end{array}$ \\
\hline 5 & $\begin{array}{l}\text { Ketersediaan } \\
\text { unsur hara(rc) }\end{array}$ & $\begin{array}{l}-\mathrm{N} \text {-total } \\
-\mathrm{K}_{2} \mathrm{O} \\
\text { - } \mathrm{P} 2 \mathrm{O} 5\end{array}$ & $\begin{array}{l}-0,17 \% \\
-0,058 \mathrm{me} / 100 \\
\text { grm } \\
-0,027 \%\end{array}$ & 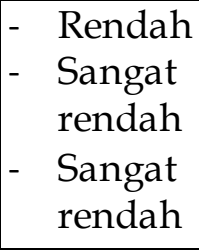 & $\begin{array}{l}\text { S1 } \\
\text { S2 } \\
\text { S2 }\end{array}$ \\
\hline 6 & $\begin{array}{l}\text { Medan/topografi } \\
(\mathrm{t})\end{array}$ & $\begin{array}{l}\text { - Lereng }(\%) \\
\text { - Batuan } \\
\text { permukaan } \\
\text { - Singkapan batuan }\end{array}$ & $\begin{array}{l}23 \% \\
<0,01 \% \\
<2 \%\end{array}$ & 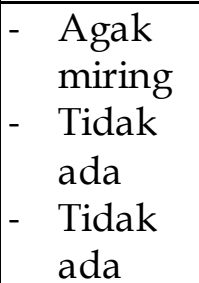 & $\begin{array}{l}\text { S3 } \\
\text { S1 } \\
\text { S1 }\end{array}$ \\
\hline
\end{tabular}

Sumber : Data olahan hasil pengukuran/Pengamatan lapangan dan Hasil analisis laboratorium Riset dan teknologi USU

Lahan Punggung

Lahan punggung berada di wilayah dusun II dan sebagian kecil 
berada di wilayah dusun III dengan titik pengambilan sampel II. Faktor pembatas pada lahan ini ialah suhu (c) dengan kelas S2, ketersediaan air ( $w$ ) dengan kelas $\mathrm{N}$. Selanjutnya Kondisi perakaran (f) yaitu drainase pada kelas S2, retensi hara (n) pada KTK dan $\mathrm{pH}$ berada pada kelas S2 dan S3, ketersediaan unsur hara (rc) pada $\mathrm{K} 2 \mathrm{O}$ yang tidak mencukupi kondisi normal dan yang terakhir yaitu lereng pada kelas S2. Parameter yang berada pada kelas S1 yaitu tekstur, kedalaman tanah, N-Total, P2O5 Batuan di
Available at http://jurnal.unimed.ac.id/2012/index.php/geo e-ISSN: 2549-7057 | p-ISSN: 2085-8167

permukaan dan Singkapan Batuan sesuai pada Tabel 2.

\section{Lahan Lembah}

Lahan lembah berada pada wilayah dusun II dan sebagian kecil pada wilayah dusun III dengan titik pengambilan sampel III. Faktor pengahambatpada lahanlembah ialah suhu (c) pada kelas S2, Ketersediaan Air (w) yang berada pada kelas N, Retensi Hara (n) yaitu KTK dan $\mathrm{pH}$ pada kelas S2.

Tabel 2. Karakteristik Lahan Pada Lahan Punggung

\begin{tabular}{|c|c|c|c|c|c|}
\hline \multirow[t]{2}{*}{ No } & \multicolumn{5}{|c|}{ Lahan Punggung } \\
\hline & Kualitas Lahan & $\begin{array}{l}\text { Karakteristik } \\
\text { Lahan }\end{array}$ & \begin{tabular}{|c|} 
Hasil \\
Pengukuran/ \\
Pengamatan
\end{tabular} & Kriteria & $\begin{array}{c}\text { Kelas } \\
\text { Kesesuaian } \\
\text { Lahan }\end{array}$ \\
\hline 1 & $\begin{array}{l}\text { Regim temperatur } \\
\text { (c) }\end{array}$ & $\begin{array}{l}\text { - Temperatur rata- } \\
\text { rata }\end{array}$ & $19,6^{\circ} \mathrm{C}$ & - & S2 \\
\hline 2 & $\begin{array}{l}\text { Ketersediaan air } \\
(\mathrm{w})\end{array}$ & - Curah hujan & $1835 \mathrm{~mm}$ & - & $\mathrm{N}$ \\
\hline 3 & $\begin{array}{l}\text { Kondisi perakaran } \\
\text { (f) }\end{array}$ & $\begin{array}{l}\text { - Drainase } \\
\text { - Tekstur } \\
\\
\text { - Kedalaman tanah }\end{array}$ & $\begin{array}{l}\text { - Agak buruk } \\
\text { - Pasir }(49 \%) \\
\text { Debu }(18 \%) \\
\text { Liat }(33 \%) \\
->60 \mathrm{~cm}\end{array}$ & $\begin{array}{l}\text { Agak } \\
\text { buruk } \\
\text { Lempung } \\
\text { liat } \\
\text { berpasir } \\
\text { - Dalam } \\
\end{array}$ & $\begin{array}{l}\mathrm{S} 2 \\
\mathrm{~S} 1 \\
\mathrm{~S} 1\end{array}$ \\
\hline 4 & Petensi hara (n) & $\begin{array}{l}\text { - KTK liat } \\
\text { - } \mathrm{pH} \mathrm{H}_{2} \mathrm{O}\end{array}$ & $\begin{array}{l}-10,12 \% \\
-5,29 \%\end{array}$ & $\begin{array}{ll}\text { - } & \text { Rendah } \\
\text { - } & \text { Agak } \\
& \text { masam }\end{array}$ & $\begin{array}{l}\text { S2 } \\
\text { S3 }\end{array}$ \\
\hline 5 & $\begin{array}{l}\text { Ketersediaan } \\
\text { unsur hara }(\mathrm{rc})\end{array}$ & $\begin{array}{l}-\mathrm{N} \text {-total } \\
-\mathrm{K}_{2} \mathrm{O} \\
-\mathrm{P} 2 \mathrm{O} 5\end{array}$ & $\begin{array}{l}0,19 \% \\
-0,069 \mathrm{me} / 100 \\
\text { grm } \\
-0,031 \%\end{array}$ & $\begin{array}{ll}\text { - } & \text { Rendah } \\
\text { - } & \text { Sangat } \\
& \text { rendah } \\
\text { - } & \text { Sangat } \\
& \text { rendah }\end{array}$ & $\begin{array}{l}\text { S1 } \\
\text { S2 } \\
\text { S2 }\end{array}$ \\
\hline 6 & $\begin{array}{l}\text { Medan/topografi } \\
\text { (t) }\end{array}$ & $\begin{array}{l}\text { - Lereng }(\%) \\
\text { - Batuan } \\
\text { permukaan } \\
\text { - Singkapan batuan }\end{array}$ & $\begin{array}{l}9 \% \\
<0,05 \% \\
<2 \%\end{array}$ & $\begin{array}{ll}\text { - } & \text { Agak } \\
& \text { miring } \\
\text { - } & \text { Tidak } \\
& \text { ada } \\
\text { - } & \text { Tidak } \\
& \text { ada } \\
\end{array}$ & $\begin{array}{l}\text { S2 } \\
\text { S1 } \\
\text { S1 }\end{array}$ \\
\hline
\end{tabular}

Parameter yang berada pada kelas S1 yang mendukung tumbuhnya tanaman bawang merah pada lahan lembah yaitu drainase, tekstur, kedalaman tanah, N-
Total, P2O5, lereng, batuan dipermukaan dan singkapan batuan. Lahan lembah merupakan lahan yang memiliki karakteristik yang dapat dilihat pada 
Tabel 3, cukup baik dibandingan jenis

lahan lainnya.

Tabel 3. Karakteristik Lahan pada Lahan Lembah

\begin{tabular}{|c|c|c|c|c|c|}
\hline \multirow[t]{2}{*}{ No. } & \multicolumn{5}{|c|}{ Lahan lembah } \\
\hline & Kualitas lahan & $\begin{array}{c}\text { Karakteristik } \\
\text { Lahan }\end{array}$ & $\begin{array}{c}\text { Hasil } \\
\text { Pengukuran/ } \\
\text { Pengamatan } \\
\end{array}$ & Kriteria & $\begin{array}{c}\text { Kelas } \\
\text { Kesesuaian } \\
\text { Lahan }\end{array}$ \\
\hline 1 & $\begin{array}{l}\text { Regim temperatur } \\
\text { (c) }\end{array}$ & $\begin{array}{l}\text { Temperatur rata- } \\
\text { rata }\end{array}$ & $19,6 \circ \mathrm{C}$ & - & S2 \\
\hline 2 & $\begin{array}{l}\text { Ketersediaan air } \\
(\mathrm{w})\end{array}$ & Curah hujan & $1835 \mathrm{~mm}$ & - & $\mathrm{N}$ \\
\hline 3 & $\begin{array}{l}\text { Kondisi perakaran } \\
\text { (f) }\end{array}$ & $\begin{array}{l}\text { Drainase } \\
\text { - Tekstur } \\
\text { - Kedalaman tanah }\end{array}$ & $\begin{array}{l}\text { - Agak baik } \\
\text { - Pasir }(55 \%) \\
\text { Debu }(20 \%) \\
\text { Liat }(25 \%) \\
->60 \mathrm{~cm}\end{array}$ & $\begin{array}{l}\text { Agak baik } \\
\text { Lempung } \\
\text { liat } \\
\text { berpasir } \\
\text { - Dalam } \\
\end{array}$ & $\begin{array}{l}\text { S1 } \\
\text { S1 }\end{array}$ \\
\hline 4 & Petensi hara (n) & $\begin{array}{l}\text { KTK liat } \\
\mathrm{pH} \mathrm{H} \mathrm{H}_{2} \mathrm{O}\end{array}$ & $\begin{array}{l}12,20 \% \\
-5,80 \%\end{array}$ & $\begin{array}{ll}\text { - } & \text { Rendah } \\
\text { - } & \text { Sangat } \\
& \text { masam }\end{array}$ & $\begin{array}{l}\text { S2 } \\
\text { S2 }\end{array}$ \\
\hline 5 & $\begin{array}{l}\text { Ketersediaan } \\
\text { unsur hara(rc) }\end{array}$ & $\begin{array}{l}\mathrm{N} \text {-total } \\
\mathrm{K}_{2} \mathrm{O} \\
\mathrm{P} 2 \mathrm{O} 5\end{array}$ & $\begin{array}{l}-0,20 \% \\
-0,091 \mathrm{me} / 100 \\
\text { grm } \\
-0,029 \%\end{array}$ & $\begin{array}{ll}\text { - } & \text { Rendah } \\
\text { - } & \text { Sangat } \\
\text { rendah } \\
\text { - } & \text { Sangat } \\
\text { rendah }\end{array}$ & $\begin{array}{l}\text { S1 } \\
\text { S2 } \\
\text { S2 }\end{array}$ \\
\hline 6 & $\begin{array}{l}\text { Medan/topografi } \\
(\mathrm{t})\end{array}$ & $\begin{array}{l}\text { Lereng }(\%) \\
\text { Batuan } \\
\text { permukaan } \\
\text { Singkapan batuan }\end{array}$ & $\begin{array}{l}-5 \% \\
-<0,01 \% \\
-<2 \%\end{array}$ & $\begin{array}{ll}\text { - } & \text { Landai } \\
\text { - } & \text { Tidak } \\
& \text { ada } \\
\text { - } & \text { Tidak } \\
& \text { ada } \\
\end{array}$ & $\begin{array}{l}\text { S1 } \\
\text { S1 } \\
\text { S1 }\end{array}$ \\
\hline
\end{tabular}

Sumber : Data olahan hasil pengukuran/Pengamatan lapangan dan Hasil analisis laboratorium Riset dan teknologi USU

\section{Lahan Landai}

Lahan landai terletak di wilayah dusun I dengan titik lokasi pengambilan sampel IV. Lahan landai memiliki parameter dengan kelas kesesuaian lahan yang juga beragam yaitu S1 (Sangat Sesuai), S2 (Cukup Sesuai), S3 (Sesuai Marginal) dan N (Tidak Sesuai). Adapun faktor penghambat pada lahan ini ialah suhu (c) dengan kelas S2, Ketersediaan air (w) pada kelas N Retensi Hara (n) yaitu KTK dan pH pada kelas S2 dan S3. Parameter yang berada pada kelas S1 yang mendukung tumbuhnya tanaman bawang merah pada lahan ini yaitu drainase, tekstur, kedalaman tanah, NTotal, P2O5, lereng, batuan dipermukaan dan singkapan batuan. Lahan landai merupakan lahan yang memiliki karakteristik yang cukup baik dibandingan jenis lahan lainnya. Karakteristik Lahan landai dapat dilihat pada Tabel 4. Unsur hara (r) pada $\mathrm{K} 2 \mathrm{O}$ kondisi tidak normal dan P2O5 berada pada kondisi hara yang tinggi. Parameter yang berada pada kelas S1 yaitu drainase, tekstur, kedalaman tanah, N-Total, lereng, batuan dipermukaan dan singkapan batuan. 
Tabel 4. Karakteristik Lahan pada Lahan Landai

\begin{tabular}{|c|c|c|c|c|c|}
\hline \multirow[b]{2}{*}{ No. } & \multicolumn{5}{|c|}{ Lahan Landai } \\
\hline & Kualitas lahan & $\begin{array}{c}\text { Karakteristik } \\
\text { Lahan }\end{array}$ & $\begin{array}{c}\text { Hasil } \\
\text { Pengukuran/ } \\
\text { Pengamatan }\end{array}$ & Kriteria & $\begin{array}{c}\text { Kelas } \\
\text { Kesesuaian } \\
\text { Lahan }\end{array}$ \\
\hline 1 & $\begin{array}{l}\text { Regim temperatur } \\
\text { (c) }\end{array}$ & $\begin{array}{l}\text { Temperatur rata- } \\
\text { rata }\end{array}$ & $19,60 \mathrm{C}$ & - & S2 \\
\hline 2 & $\begin{array}{l}\text { Ketersediaan air } \\
(\mathrm{w})\end{array}$ & Curah hujan & $1835 \mathrm{~mm}$ & - & $\mathrm{N}$ \\
\hline 3 & $\begin{array}{l}\text { Kondisi perakaran } \\
\text { (f) }\end{array}$ & $\begin{array}{l}\text { Drainase } \\
\text { Tekstur } \\
\text { Kedalaman tanah }\end{array}$ & $\begin{array}{l}- \text { - Agak baik } \\
\text { - Pasir }(43 \%) \\
\text { Debu (12 \%) } \\
\text { Liat }(45 \%) \\
->60 \mathrm{~cm}\end{array}$ & $\begin{array}{l}\text { - Agak } \\
\text { baik } \\
\text { - Liat } \\
\text { - Dalam }\end{array}$ & $\begin{array}{l}\text { S1 } \\
\text { S1 } \\
\text { S1 }\end{array}$ \\
\hline 4 & Petensi hara (n) & $\begin{array}{l}\text { KTK liat } \\
\mathrm{pH} \mathrm{H} \mathrm{H}_{2} \mathrm{O}\end{array}$ & \begin{tabular}{|l}
$-10,12 \%$ \\
$-5,38 \%$
\end{tabular} & $\begin{array}{ll}- & \text { Rendah } \\
\text { - } & \text { Agak } \\
& \text { masam } \\
\end{array}$ & $\begin{array}{l}\text { S2 } \\
\text { S3 }\end{array}$ \\
\hline 5 & $\begin{array}{l}\text { Ketersediaan } \\
\text { unsur hara(rc) }\end{array}$ & $\begin{array}{l}\mathrm{N} \text {-total } \\
\mathrm{K}_{2} \mathrm{O} \\
\mathrm{P} 2 \mathrm{O} 5\end{array}$ & $\begin{array}{l}-0,18 \% \\
-0,075 \text { me/100 } \\
\text { grm } \\
-0,041 \%\end{array}$ & $\begin{array}{ll}\text { - } & \text { Rendah } \\
\text { - } & \text { Sangat } \\
\text { rendah } \\
\text { - } & \text { Sangat } \\
& \text { rendah }\end{array}$ & $\begin{array}{l}\text { S1 } \\
\text { S2 } \\
\text { S2 }\end{array}$ \\
\hline 6 & $\begin{array}{l}\text { Medan/topografi } \\
\text { (t) }\end{array}$ & $\begin{array}{l}\text { Lereng (\%) } \\
\text { Batuan permukaan } \\
\text { Singkapan batuan }\end{array}$ & $\begin{array}{l}-5 \% \\
-<0,01 \% \\
-<2 \%\end{array}$ & $\begin{array}{ll}\text { - } & \text { Landai } \\
\text { - } & \text { Tidak } \\
\text { ada } \\
\text { - } \\
\text { Tidak } \\
\text { ada } \\
\end{array}$ & $\begin{array}{l}\text { S1 } \\
\text { S1 } \\
\text { S1 }\end{array}$ \\
\hline
\end{tabular}

Sumber : Data olahan hasil pengukuran/Pengamatan lapangan dan Hasil analisis laboratorium Riset dan teknologi USU

Dari data tersebut dapat pula dilihat secara kesesuluhan faktor utama penyebab bawang merah tidah baik dibudidayakan di Desa Pasaran Parsaoran akibat tingginya curah hujan dan berada pada kelas $\mathrm{N}$ atau tidak sesuai yang disajikan pada Tabel 5.

Tabel 5. Kelas Kesesuaian Lahan di Desa Pasaran Parsaoran, 2017

\begin{tabular}{|c|c|c|c|c|c|}
\hline No. & \multirow[b]{2}{*}{$\begin{array}{c}\text { Kualitas Lahan berdasar } \\
\text { karakteristik lahan }\end{array}$} & \multicolumn{4}{|c|}{$\begin{array}{l}\text { Lokasi } \\
\end{array}$} \\
\hline & & $\begin{array}{l}\text { Lahan } \\
\text { lereng }\end{array}$ & $\begin{array}{c}\text { Lahan } \\
\text { punggung }\end{array}$ & $\begin{array}{r}\text { Lahan } \\
\text { lembah }\end{array}$ & $\begin{array}{l}\text { Lahan } \\
\text { landai }\end{array}$ \\
\hline 1. & Regim temperatur (Tc) & S2 & S2 & S2 & S2 \\
\hline 2. & $\begin{array}{l}\text { Ketersediaan air }(\mathrm{w}) \\
\text { - Curah hujan }\end{array}$ & $\mathrm{N}$ & $\mathrm{N}$ & $\mathrm{N}$ & $\mathrm{N}$ \\
\hline 3. & $\begin{array}{l}\text { Kondisi perakaran (f) } \\
\text { - Drainase } \\
\text { - Tekstur } \\
\text { - Kedalaman tanah } \\
\text { Rating kualitas }\end{array}$ & $\begin{array}{l}\text { S2 } \\
\text { S1 } \\
\text { S1 } \\
\text { S2f }\end{array}$ & $\begin{array}{l}\text { S2 } \\
\text { S1 } \\
\text { S1 } \\
\text { S2f }\end{array}$ & $\begin{array}{l}\text { S1 } \\
\text { S1 } \\
\text { S1 } \\
\text { S1 }\end{array}$ & $\begin{array}{l}\text { S1 } \\
\text { S1 } \\
\text { S1 } \\
\text { S1 }\end{array}$ \\
\hline 4. & $\begin{array}{l}\text { Retensi Hara (n) } \\
\text { - KTK Liat }\end{array}$ & S2 & S2 & S2 & S2 \\
\hline
\end{tabular}




\begin{tabular}{|c|c|c|c|c|c|}
\hline \multirow[t]{2}{*}{ No. } & \multirow[b]{2}{*}{$\begin{array}{c}\text { Kualitas Lahan berdasar } \\
\text { karakteristik lahan }\end{array}$} & \multicolumn{4}{|c|}{ Lokasi } \\
\hline & & $\begin{array}{l}\text { Lahan } \\
\text { lereng }\end{array}$ & $\begin{array}{c}\text { Lahan } \\
\text { punggung }\end{array}$ & $\begin{array}{r}\text { Lahan } \\
\text { lembah }\end{array}$ & $\begin{array}{l}\text { Lahan } \\
\text { landai }\end{array}$ \\
\hline & $\begin{array}{l}-\mathrm{pHH}_{2} \mathrm{O} \\
\text { Rating kualitas }\end{array}$ & $\begin{array}{l}\text { S3 } \\
\text { S3n }\end{array}$ & $\begin{array}{l}\text { S3 } \\
\text { S3n }\end{array}$ & $\begin{array}{l}\text { S2 } \\
\text { S2n }\end{array}$ & $\begin{array}{l}\text { S3 } \\
\text { S3n }\end{array}$ \\
\hline 5. & $\begin{array}{l}\text { Ketersediaan unsur hara }(\mathrm{rc}) \\
-\mathrm{N} \text {-Total } \\
-\mathrm{K}_{2} \mathrm{O} \\
-\mathrm{P}_{2} \mathrm{O}_{5} \\
\text { Rating kualitas }\end{array}$ & $\begin{array}{l}\text { S1 } \\
- \\
\text { S1 } \\
\text { S1 }\end{array}$ & $\begin{array}{l}\text { S1 } \\
- \\
\text { S1 } \\
\text { S1 }\end{array}$ & $\begin{array}{l}\text { S1 } \\
- \\
\text { S1 } \\
\text { S1 }\end{array}$ & $\begin{array}{l}\text { S1 } \\
- \\
\text { S1 } \\
\text { S1 }\end{array}$ \\
\hline 6. & $\begin{array}{l}\text { Topografi }(\mathrm{t}) \\
\text { - Lereng } \\
\text { - Batuan permukaan } \\
\text { - Singkapan batuan } \\
\text { Rating kualitas } \\
\text { Kelas Kesesuaian Lahan }\end{array}$ & $\begin{array}{l}\text { S3 } \\
\text { S1 } \\
\text { S1 } \\
\text { S3t } \\
\text { Nw }\end{array}$ & $\begin{array}{l}\text { S2 } \\
\text { S1 } \\
\text { S1 } \\
\text { S2t } \\
\text { Nw }\end{array}$ & $\begin{array}{l}\text { S1 } \\
\text { S1 } \\
\text { S1 } \\
\text { S1 } \\
\text { Nw }\end{array}$ & $\begin{array}{l}\text { S1 } \\
\text { S1 } \\
\text { S1 } \\
\text { S1 } \\
\text { Nw }\end{array}$ \\
\hline
\end{tabular}

Sumber : Data olahan 2017

Berdasarkan Tabel 5 diketahui keempat lahan memiliki curah hujan yang tinggi dengan kelas N. Berdasarkan teori tumbuhnya tanaman bawang merah tidak dapat hidup dengan baik pada kondisi curah hujan yang tinggi atau tanah tidak boleh dalam keadaan becek. Dari keempat lahan tersebut berdasarkan kondisi relief lahan, lahan yang memiliki potensi paling besar mengalirkan air paling cepat sehingga lebih sulit mengalami jenuh air adalah Lahan lereng karena memiliki kemiringan lereng yang lebih besar, sehingga lahan untuk tanaman bawang merah sulit mengalami becek atau basah dalam jangka lama, namun berdasarkan ketersediaan unsur hara dan menahan unsur hara, kondisi tersebut lebih mudah mengalami kehilangan unsur hara tanah.

Sedangkan lahan yang memiliki jumlah hara yang cukup banyak berada pada lahan lembah dan lahan landai, namun lahan ini memiliki potensi yang besar untuk menyumpan air yang menyebabkan tanah mudah mengalami penjenuhan. Perlunya pola musim tanam sangat menguntungkan dalam mebudidayakan tanaman bawang merah. berdasarkan data curah hujan Desa Pasaran parsaoran dari kantor Stasiun BMKG sampali Medan diketahui pola bulan-bulan untuk musim tanam yang tepat yang disajikan pada Tabel 6 .

Tabel 6. Data Curah Hujan Bulanan Kecamatan Nainggolan

\begin{tabular}{|l|l|l|l|l|l|l|l|l|l|l|l|l|l|}
\hline \multirow{2}{*}{ Tahun } & \multicolumn{10}{|c|}{$\mathbf{~} \mathbf{1} \mathbf{~ a ~ n ~ ( m m ) ~}$} & $\begin{array}{l}\text { Jml } \\
(\mathbf{m m})\end{array}$ \\
\cline { 2 - 16 } & $\mathbf{1}$ & $\mathbf{2}$ & $\mathbf{3}$ & $\mathbf{4}$ & $\mathbf{5}$ & $\mathbf{6}$ & $\mathbf{7}$ & $\mathbf{8}$ & $\mathbf{9}$ & $\mathbf{1 0}$ & $\mathbf{1 1}$ & $\mathbf{1 2}$ & $\mathbf{( 1 2 4}$ \\
\hline 2007 & 147 & 57 & 110 & 310 & 135 & 294 & 0 & 124 & 101 & 190 & 173 & 123 & 1764 \\
\hline 2008 & 175 & 81 & 303 & 294 & 99 & 74 & 222 & 259 & 80 & 372 & 124 & 333 & 2416 \\
\hline 2009 & 218 & 165 & 284 & 129 & 17 & 93 & 22 & 209 & 153 & 39 & 147 & 293 & 1769 \\
\hline 2010 & 198 & 130 & 190 & 298 & 198 & 145 & 131 & 156 & 272 & 161 & 179 & 258 & 2316 \\
\hline 2011 & 100 & 123 & 104 & 120 & 26 & 19 & 111 & 191 & 172 & 236 & 266 & 245 & 1713 \\
\hline 2014 & 143 & 77 & 124 & 201 & 148 & 79 & 101 & 175 & 177 & 211 & 213 & 241 & 1890 \\
\hline 2015 & 190 & 90 & 144 & 243 & 163 & 95 & 37 & 112 & 177 & 138 & 203 & 214 & 1806 \\
\hline 2016 & 18 & 82 & 40 & 162 & 198 & 58 & 64 & 43 & 84 & 34 & 120 & 105 & 1008 \\
\hline $\begin{array}{l}\text { Rerata } \\
\text { bulanan }\end{array}$ & 149 & 101 & 162 & 220 & 123 & 107 & 86 & 158 & 152 & 172 & 178 & 226 & 1.835 \\
\hline
\end{tabular}

Keterangan: Tahun 2012 dan 2013 tidak disertakan karena ketidaklengkapan data

Sumber: Kantor BMKG Sampali, 2017 
Berdasarkan tabel 6 tersebut, diketahui jumlah bulan basah dan bulan kering pada setiap bulan dalam delapan tahun. Data tersebut digunakan untuk mengetahui pola musim tanam yang baik untuk tanaman bawang merah. bawang merah dapat tumbuh pada kondisi tidak Tabel 7. Jumlah Bulan Basah dan Bulan Kering Berdasarkan Waktu Musim Tanam bawang Merah

\begin{tabular}{|c|c|c|c|c|c|c|c|c|c|c|c|c|c|}
\hline \multirow{2}{*}{ No } & \multirow{2}{*}{ Jenis Bulan } & \multicolumn{12}{|c|}{$\mathrm{Bulan}$} \\
\hline & & 1 & 2 & 3 & 4 & 5 & 6 & 7 & 8 & 9 & 10 & 11 & 12 \\
\hline 1 & Bulan Basah & 6 & 3 & 7 & 8 & 5 & 3 & 4 & 7 & 6 & 6 & 8 & 8 \\
\hline 2 & Bulan Lembab & 1 & 4 & - & - & 1 & 4 & 1 & - & 2 & - & - & - \\
\hline 3 & Bulan Kering & 1 & 1 & 1 & - & 2 & 2 & 3 & 1 & - & 2 & - & - \\
\hline
\end{tabular}

Sumber : Data Olahan, 2017

Berdasarkan Tabel 7 dapat diketahui bahwa bulan kering terjadi pada bulan Februari, Mei, Juni, Juli dan Oktober, bulan basah terjadi pada bulan Januari, Maret, April, Agustus, September, November dan Desember. Data bulan basah dan bulan kering ini dapat dijadikan sebagai pedoman dalam menentukan pola musim tanam yang tepat untuk penanaman bawang merah. terlalu basah dan tidak terlalu kering. Untuk wilayah Samosir khususnya Kecamatan Nainggolan, bawang merah sesuai ditanam pada saat kondisi bulan kering. Berikut data bulan basah, bulan lembab dan bulan kering di Kecamatan Nainggolan yang disajikan pada Tabel 7.

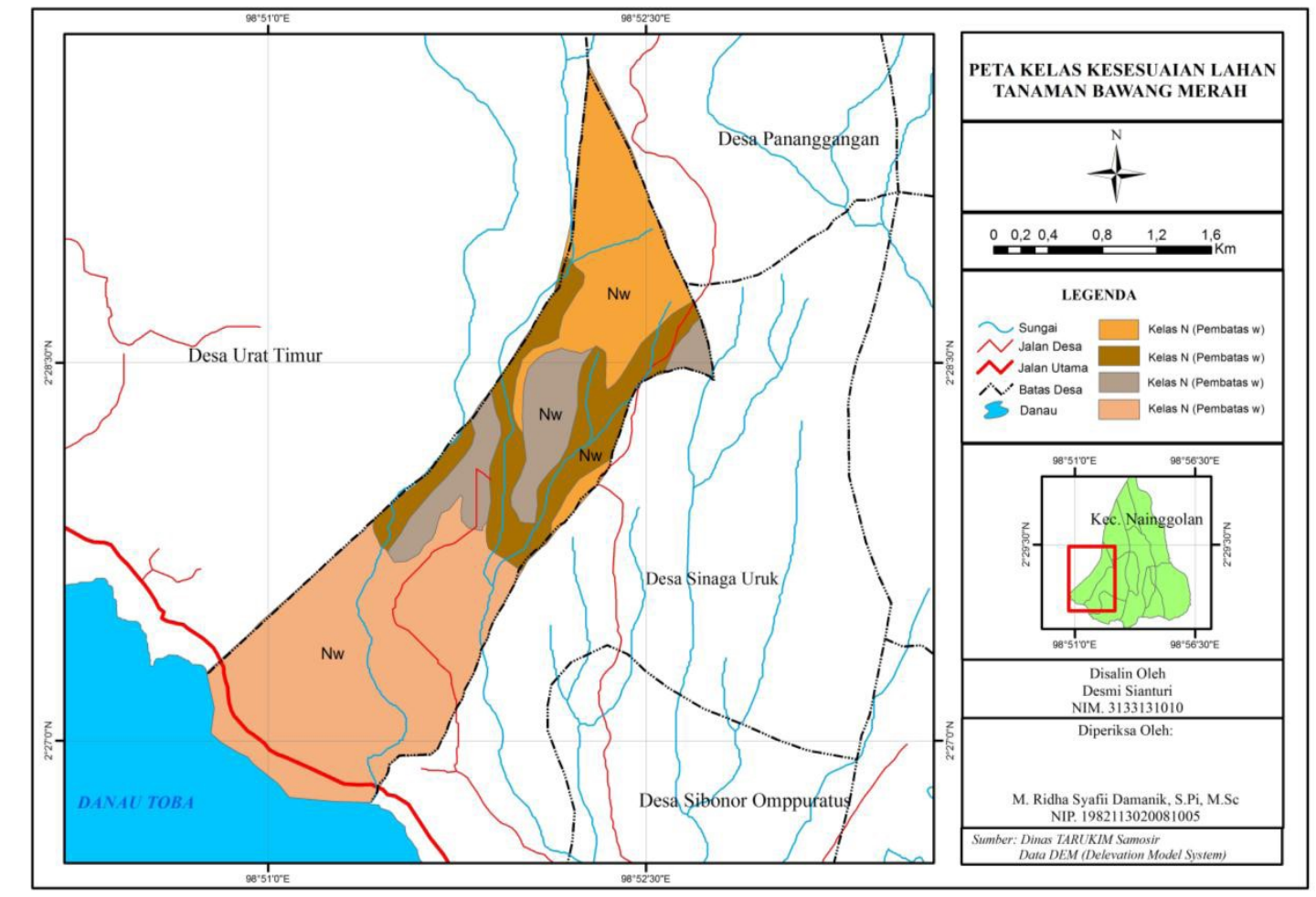

Gambar 2. Peta Kelas Kesesuaian Lahan Untuk Tanaman Bawang Merah di Desa Pasaran Parsaoran 


\section{KESIMPULAN DAN SARAN}

Desa Pasaran Parsaoran berada pada kelas kesesualan lahan Nw memiliki kondisi curah hujan yang tinggi. Lahan yang memiliki pembatas paling banyak berada pada wilayah dusun III dengan faktor pembatasnya curah hujan yang tinggi (w) pada kelas $\mathrm{N}, \mathrm{pH}$ tanah dan lereng pada kelas S3, suhu, drainase, KTK, pada kelas S2. Sedangkan lahan yang memiliki penghambat paling sedikit berada pada sekitar wilayah dusun II dengan faktor pembatas ketersediaan air berada pada kelas N. pH tanah, suhu, KTK, pada kelas S2 dan faktor pendukungnya ialah tekstur, kedalaman efektif tanah, N-Total, P2O5, batuan dipermukaan, dan singkapan batuan yang berada pada kelas S1.

Masalah pada curah hujan yang terlalu tinggi dapat diatasi dengan memperhatikan pola musim tanam berdasarkan bulan basah dan bulan kering daerah tersebut. Serta membuat bedengan untuk lahan tanaman bawang merah agar menghindari tanah dalam kondisi basah/becek.

\section{DAFTAR PUSTAKA}

$\begin{array}{lrr}\text { Delita, F. (2016). } & \text { STUDI } & \text { PERUBAHAN } \\ \text { TUTUPAN } & \text { LAHAN } & \text { UNTUK } \\ \text { PERMUKIMAN } & \text { SEBELUM } & \text { DAN } \\ \text { SESUDAH GEMPA PADANG 2009 DI } \\ \text { KECAMATAN KOTO TANGAH KOTA } \\ \text { PADANG PROVINSI SUMATERA } \\ \text { BARAT. JURNAL GEOGRAFI, 8(1). }\end{array}$

Rahmad, R., \& Haryono, E. (2013). PENDUGAAN EROSI, SEDIMEN, DAN SKENARIO PENGUNAAN LAHAN MENGGUNAKAN ArcSWAT2009 (Studi Kasus: DAS Batang Arau, DAS Batang Kuranji, dan DAS Batang Air Dingin)(Doctoral dissertation, [Yogyakarta]: Universitas Gadjah Mada).

Sianipar, Joindida, dkk. 2015. Karakterisasi dan Evaluasi Morfologi
Bawang Merah Lokal Samosir (Allium ascalonicum L.) pada Beberapa Aksesi di Kecamatan Bakti Raja, Agroekoteknologi. Vol.4 No.1.

Wibowo, Singgih. 2009. Budidaya Bawang. Jakarta: PenebarSwadaya

Siswanto. 2006. Evaluasi Sumberdaya Lahan. Surabaya: UPN Press

Dirjen Holtikultura. 2016. (Online). (http://aplikasi.pertanian.go.id/bdsp Lhasil_kom.asp.Diakses tanggal 17 Maret 2017)

Litbang Pertanian. 2015. (Online).www.litbang.pertanian.go.id . Akses 22 Januari 2017. 